\title{
Repair of the Nervous System
}

\author{
David G. McLone, Editor-in-Chief
}

Most of our neurosurgical history has seen the evolution of surgical procedures to remove masses, tumor, hematoma or CSF. Other procedures are directed at malformation, both congenital and acquired. These include myelomeningoceles, encephaloceles and vascular malformations. Only recently have we begun to speak of repair of the nervous system.

It began with recombinant DNA technology, fetal tissue transplant and now stem cell research.

Stem cells are embryonic multi-potential cells. Stem cells can be cultured and now coaxed into differentiation along desired lines of tissue development. Examples of this would be stem cell differentiation into oligodendroglial cells, astrocytes or neurons. This alone is amazing, but recently McKay at the NIH has shown that depleted neurons in the brains of rodents can be replaced by stem cells. These cells not only migrate from the ventricular system to where they are needed, but once they arrive, they establish appropriate synaptic contacts and axonal connections. Choi at Washington University restored function by repairing the spinal cord of a rat with stem cells. This was accomplished several days following the injury to the spinal cord.

An ethical issue remains to be overcome. The only source of these cells at present is embryonic tissue. Thus, human stem cells require human embryos for harvest. It is very likely that in the near future a source of stem cells will be found in each individual patient that can be used for their own repair.

It is important that pediatric neurosurgeons stay current with this research and get involved in both the research and clinical applications. The delivery of these cells will require a surgical procedure to introduce them. It is likely that practical nervous system repair will be possible within 5-10 years. Repair will likely begin with Alzheimer and Parkinson's disease, but will quickly move to repair of traumatic lesions. It is hoped that repair of congenital lesions, even during fetal life will follow.

\begin{tabular}{ll}
\hline KARGER & ○ 2000 S. Karger AG, Basel \\
$1016-2291 / 00 / 0324-0169 \$ 17.50 / 0$ \\
$\begin{array}{l}\text { Fax +4161306 1234 } \\
\begin{array}{l}\text { E-Mail karger@karger.ch } \\
\text { www.karger.com }\end{array}\end{array}$ & $\begin{array}{l}\text { Accessible online at: } \\
\text { www.karger.com/journals/pne }\end{array}$
\end{tabular}

